\title{
Assessing the impact of road traffic on cycling for leisure and cycling to work
}

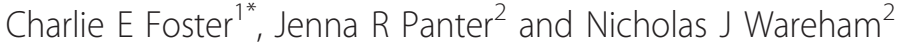

\begin{abstract}
Background: To explore the relationship between leisure and commuter cycling with objectively measured levels of road traffic and whether any relationship was affected by traffic levels directly outside of home or in local neighbourhood.

Findings: We conducted a secondary analysis of data from the UK European Prospective Investigation of Cancer (EPIC) Norfolk cohort in 2009. We used a geographical information system (GIS) and gender specific multivariate models to relate 13927 participants' reported levels of cycling with an index of road traffic volume (Road Traffic Volume Index Score - RTVIS). RTVIS were calculated around each participants home, using four distance based buffers, $(0.5 \mathrm{~km}, 1 \mathrm{~km}, 2 \mathrm{~km}$ and $3.2 \mathrm{~km})$. Models were adjusted for age, social status, education, car access and deprivation. Both genders had similar decreases in leisure cycling as traffic volumes increased at greater distances from home (OR 0.42, (95\% Cl 0.32-0.52, p < 0.001) for women and OR 0.41, (95\% Cl 0.33-0.50, p < 0.001) for men in the highest quartile at $3.2 \mathrm{~km}$ ). There was no effect of traffic volumes at any distance on commuter cycling.

Conclusions: Traffic volumes appear to have greater impact on leisure cycling than commuter cycling. Future research should investigate the importance of traffic on different types of cycling and include psychosocial correlates.
\end{abstract}

Keywords: Cycling, traffic, GIS

\section{Background}

Cycling is considered to be a healthy, low carbon and sustainable physical activity behaviour [1]. Although travel by bicycle does introduce health risks through accidents and injuries [2] the health benefits of cycling have been shown to outweigh these risks [3]. More specifically, studies have suggested that commuter cyclists have a lower mortality risk than non-cycling commuters, independent of physical activity levels [4]. Across many international countries the numbers of car trips are increasing and in some there are simultaneous declines in active travel trips by walking or cycling [5].

Characteristics of the built environment are also suspected to contribute to levels of walking and cycling [6], although for active travel behaviors in particular the evidence is inconsistent [7]. It could be hypothesized that

\footnotetext{
* Correspondence: charlie.foster@dphpc.ox.ac.uk

'Department of Public Health, University of Oxford, UK

Full list of author information is available at the end of the article
}

in areas which have both unsupportive built environments for active travel and high traffic volumes, a double burden of negative associations for active travel could be produced. International studies have focused on the negative impact of perceptions of traffic levels and safety on walking and cycling but have not used objective measures of traffic volume $[8,9]$.

In our previous study, exposure to higher levels of traffic around the home was associated with less leisure cycling [10]. The aim of this study was to (i) explore the relationship between leisure cycling and commuter cycling with objectively measured levels of road traffic derived using a geographical information system (GIS) and (ii) investigate if any relationship was affected by traffic levels directly outside of the home or between home and local destinations.

\section{Methods}

The UK EPIC-Norfolk study was designed as a prospective cohort study and the methods of recruitment, sampling and overall sample representativeness have been
Ciomed Central

() 2011 Foster et al; licensee BioMed Central Ltd. This is an Open Access article distributed under the terms of the Creative Commons Attribution License (http://creativecommons.org/licenses/by/2.0), which permits unrestricted use, distribution, and reproduction in any medium, provided the original work is properly cited. 
described elsewhere [11]. Data on self-reported measures of physical activity was collected from 15,786 adults using EPAQ2 between 1998 and 2000. This questionnaire asks about the frequency and duration of physical activity at home, at work (including travel to work) and for recreation, over the past 12 months. Ethical approval for the EPIC-Norfolk study was given by the Norfolk Research Ethics Committee.

Participants were asked to report how often they used a bicycle to get to work using the response categories of 'always', 'usually', occasionally' and 'never or rarely'. Participants were classified as commuter cycling if they reported 'always' travelling to work by bicycle. Leisure cycling was assessed by three items which asked about the number of occasions of cycling for pleasure, for racing and rough terrain cycling. If participants reported at least 1 occasion of any of these activities they were classified as engaging in 'some' leisure cycling.

Objective measures of road traffic volume were estimated using a GIS (ESRI ArcGIS 9.2). We calculated a proxy measure of traffic volume (Road Traffic Volume Index Score - RTVIS) for each participant using four different distance based buffers around each individuals home postcode $(0.5 \mathrm{~km}, 1 \mathrm{~km}, 2 \mathrm{~km}, 3.2 \mathrm{~km})$. It was calculated by computing the total lengths of four different types of road (principal roads or motorways, A-roads (major roads), B-roads (minor or local roads) and unclassified roads) within these buffers (centred on participants' homes) and weighting these based on the average road speed for each classification [12]. Scores were divided into quartiles and the lowest quartile was used as the reference group. Using a variety of distance buffers allowed us to examine any potential differences in the associations between cycling behaviour and traffic volume at different proximities, as there is currently uncertainty about size of the area from home which influences commuting or leisure related activities. The choice of the largest radius size reflected the UK government's aim to encourage a shift from car use to walking or cycling for short journeys under 2 miles $(3.2 \mathrm{~km})$ [13]. We estimated that a 2 mile cycle journey (at $8 \mathrm{mph}$ ) should take an adult approximately 15 minutes.

Possible confounders included age, gender, social status, educational qualifications, area socioeconomic deprivation, car ownership, ethnicity, and self-reported health conditions.

We built a series of gender specific multivariate models to calculate the odds ratios of commuter and leisure cycling associated with RTVIS adjusted for identified confounders. We checked for effect modification and interactions between variables at each stage of the model [14].

\section{Results}

Physical activity data were available for 15572 participants, however we excluded those who had incomplete postcode data or had moved out of the study area (5.9\%), unusually high levels of self reported physical activity (1.5\%) and missing socio-demographic data (3.1\%). This left 13927 participants for analysis.

Table 1 shows the characteristics of the sample. A higher proportion of men reported any leisure cycling compared to women, however we found a slightly higher proportion of women reported any occasions of commuter cycling than men $(\mathrm{p}<0.05)$.

Table 2 presents the adjusted odds ratios for reporting leisure and commuter cycling.

Using a $500 \mathrm{~m}$ buffer, an increasing RTVIS was associated with higher odds of leisure cycling and women's commuter cycling. Yet, with larger buffer sizes the odds of leisure cycling decreased with increasing RTVIS, however there were no such associations observed for commuter cycling for either genders.

\section{Conclusions}

Exposure to increasing level of traffic around home was associated with a reduction in leisure cycling and not for commuter cycling. Both genders had similar decreases in leisure cycling as traffic volumes increased between $500 \mathrm{~m}$ to $1000 \mathrm{~m}$ from home.

A few studies have reported conflicting associations between characteristics of the built environment, traffic and different types of cycling behaviour $[8,15,16]$. However direct comparison is difficult due to differences in methods in construction of the outcome variable by combining walking and cycling, or all cycling or cycle path use. One case study of non-cyclists reported similar impacts of traffic made cycling dangerous based on a combination of the poor quality of the road environment, plus heavy and speeding traffic, and worries about the dangers of cycling [17].

Triano and Freedson recently identified that a diversity of non-comparable methods are a limitation to environmental/behavioral research [18]. This study was limited by use of a non-objective physical activity measure however data were collected before the possible application of such measures could be realistically used in such a large sample. Outcome variable data were collected using appropriate methods for a large cohort study, using a reliable and valid measure. The GIS derived exposure measure is based on road transport network and local road speed, which could easily be adopted by other researchers to make cross-study and country comparisons possible. The use of increasing buffer areas for traffic also avoided any potential interindividual variation in the size of neighbourhood and 
Table 1 Characteristics of participants by socio-demographic, physical activity and environmental variables

\begin{tabular}{|c|c|c|c|c|c|c|c|c|}
\hline & \multicolumn{4}{|c|}{ Men $(n=6134)$} & \multicolumn{4}{|c|}{ Women $(n=7793)$} \\
\hline & \multicolumn{2}{|c|}{ Occasions of leisure cycling } & \multicolumn{2}{|c|}{ Occasions of commuter cycling } & \multicolumn{2}{|c|}{ Occasions of leisure cycling } & \multicolumn{2}{|c|}{ Occasions of commuter cycling } \\
\hline & None & Any & None & Any & None & Any & None & Any \\
\hline Percentage of Subjects & 80.1 & 19.9 & 96.2 & 3.8 & 85.1 & 14.9 & 95.7 & 4.3 \\
\hline \multicolumn{9}{|l|}{ Age } \\
\hline $41-50$ years of age & 63.9 & $36.1^{*}$ & 91.4 & $8.6^{*}$ & 70.1 & $29.9^{*}$ & 91.5 & $8.5^{*}$ \\
\hline $51-60$ years of age & 73.0 & 27.0 & 93.4 & 6.6 & 80.4 & 19.6 & 93.2 & 6.8 \\
\hline $61-70$ years of age & 82.7 & 17.3 & 97.6 & 2.4 & 893. & 10.7 & 97.9 & 2.1 \\
\hline $71-80$ years of age & 91.6 & 8.4 & 99.5 & 0.5 & 95.5 & 4.5 & 99.4 & 0.6 \\
\hline \multicolumn{9}{|l|}{ Social status } \\
\hline Professional & 75.4 & $24.6^{*}$ & 95.0 & $5.0^{*}$ & 82.8 & $17.2^{*}$ & 95.2 & $4.8^{*}$ \\
\hline Managerial \& Tech. & 80.0 & 20.0 & 97.7 & 2.3 & 84.0 & 16.0 & 97.0 & 3.0 \\
\hline Skilled non-manual & 80.6 & 19.4 & 97.1 & 2.9 & 88.9 & 11.1 & 97.3 & 2.7 \\
\hline Skilled manual & 80.1 & 19.9 & 95.1 & 4.9 & 83.9 & 16.1 & 94.9 & 5.1 \\
\hline Partly skilled & 82.2 & 17.8 & 93.3 & 6.7 & 85.5 & 14.5 & 92.4 & 7.6 \\
\hline Unskilled & 85.1 & 14.9 & 94.2 & 5.8 & 84.2 & 15.8 & 91.0 & 9.0 \\
\hline \multicolumn{9}{|l|}{ Educational qualifications } \\
\hline Degree or higher & 76.1 & $23.9^{*}$ & 95.9 & 4.1 & 80.4 & $19.6^{*}$ & 95.3 & 4.7 \\
\hline Any qualifications & 78.9 & 21.1 & 96.4 & 3.6 & 83.3 & 16.7 & 96.3 & 3.7 \\
\hline No qualifications & 85.0 & 15.0 & 95.7 & 4.3 & 88.2 & 11.8 & 95.5 & 4.5 \\
\hline \multicolumn{9}{|l|}{ Car ownership } \\
\hline Yes & 80.7 & $19.3^{*}$ & 97.3 & $2.7^{*}$ & 85.0 & 15.0 & 97.0 & $3.0^{*}$ \\
\hline No & 75.7 & 24.3 & 88.2 & 11.8 & 85.2 & 14.8 & 91.0 & 9.0 \\
\hline \multicolumn{9}{|l|}{ Townsend index } \\
\hline Quintile 1 (most affluent) & 80.2 & 19.8 & 97.8 & $2.2^{*}$ & 86.2 & $13.8^{*}$ & 96.9 & $3.1^{*}$ \\
\hline Quintile 2 & 79.3 & 20.7 & 96.3 & 3.7 & 86.4 & 13.6 & 97.1 & 2.9 \\
\hline Quintile 3 & 78.6 & 21.4 & 96.4 & 3.6 & 82.2 & 17.8 & 95.7 & 4.3 \\
\hline Quintile 4 & 80.5 & 19.5 & 96.3 & 3.7 & 83.9 & 16.1 & 95.9 & 4.1 \\
\hline Quintile 5 (most deprived) & 81.9 & 18.1 & 93.9 & 6.1 & 86.5 & 13.5 & 93.1 & 6.9 \\
\hline \multicolumn{9}{|l|}{ Self-reported health } \\
\hline With condition & 82.3 & $17.7^{*}$ & 97.4 & $2.6^{*}$ & 86.8 & $13.2^{*}$ & 96.1 & 3.9 \\
\hline Without condition & 78.4 & 21.6 & 95.2 & 4.8 & 83.0 & 17.0 & 95.4 & 4.6 \\
\hline
\end{tabular}

* Signifies significant trend across variable categories at $P<.05$. 
Table 2 Odds ratios $(95 \% \mathrm{Cl})$ for reporting leisure and commuter cycling in past month by quartiles of Road Traffic Volume Index Score

\begin{tabular}{|c|c|c|c|c|}
\hline & \multicolumn{2}{|c|}{ Odds of leisure cycling $(95 \% \mathrm{Cl})$ a } & \multicolumn{2}{|c|}{ Odds of commuter cycling $(95 \% \mathrm{Cl}) \mathrm{b}$} \\
\hline & Men & Women & Men & Women \\
\hline \multicolumn{5}{|l|}{ RTVIS within $500 \mathrm{~m}$} \\
\hline Quartile 1 (Light Traffic) & 1.00 & 1.00 & 1.00 & 1.00 \\
\hline Quartile 2 & $1.11(0.92-1.34)$ & $1.11(0.92-1.34)$ & $0.73(0.50-1.07)$ & $1.14(0.82-1.57)$ \\
\hline Quartile 3 & $1.80(0.98-1.42)$ & $1.16(0.97-1.40)$ & $0.71(0.48-1.04)$ & $1.06(0.76-1.50)$ \\
\hline Quartile 4 (Heavy Traffic) & $1.23(1.02-1.48)$ & $1.05(0.88-1.26)$ & $0.76(0.53-1.12)$ & $1.20(0.87-1.66)$ \\
\hline \multicolumn{5}{|l|}{ RTVIS within $1000 \mathrm{~m}$} \\
\hline Quartile 1 (Light Traffic) & 1.00 & $1.00^{*}$ & 1.00 & 1.00 \\
\hline Quartile 2 & $0.89(0.74-1.06)$ & $0.71(0.60-0.85)$ & $0.80(0.50-1.28)$ & $1.27(0.89-1.81)$ \\
\hline Quartile 3 & $0.73(0.61-0.88)$ & $0.47(0.39-0.57)$ & $1.60(1.06-2.39)$ & $1.37(0.97-1.94)$ \\
\hline Quartile 4 (Heavy Traffic) & $0.49(0.40-0.60)$ & $0.48(0.39-0.58)$ & $1.27(0.83-1.93)$ & $1.01(0.70-1.46)$ \\
\hline \multicolumn{5}{|l|}{ RTVIS within $2000 \mathrm{~m}$} \\
\hline Quartile 1 (Light Traffic) & $1.00^{*}$ & $1.00^{*}$ & 1.00 & 1.00 \\
\hline Quartile 2 & $0.83(0.70-0.99)$ & $0.68(0.57-0.80)$ & $1.08(0.69-1.70)$ & $1.44(1.01-2.04)$ \\
\hline Quartile 3 & $0.68(0.56-0.81)$ & $0.51(0.42-0.61)$ & $1.64(1.07-2.50)$ & $1.34(0.94-1.91)$ \\
\hline Quartile 4 (Heavy Traffic) & $0.43(0.35-0.53)$ & $0.43(0.35-0.52)$ & $1.53(1.00-2.34)$ & $1.10(0.76-1.60)$ \\
\hline \multicolumn{5}{|l|}{ RTVIS within 3200 m } \\
\hline Quartile 1 (Light Traffic) & $1.00^{*}$ & $1.00^{*}$ & 1.00 & 1.00 \\
\hline Quartile 2 & $0.77(0.65-0.92)$ & $0.71(0.60-0.84)$ & $0.86(0.54-1.36)$ & $1.67(0.17-2.36)$ \\
\hline Quartile 3 & $0.61(0.51-0.74)$ & $0.47(0.39-0.57)$ & $1.58(1.04-2.37)$ & $1.14(0.78-1.65)$ \\
\hline Quartile 4 (Heavy Traffic) & $0.41(0.33-0.50)$ & $0.42(0.35-0.52)$ & $1.31(0.86-2.00)$ & $1.11(0.76-1.61)$ \\
\hline
\end{tabular}

${ }^{*} p$ value test for trend $<0.001$

a Models adjusted for age, social status, education, car ownership, travel mode to work, occupational physical activity.

b Models adjusted for age, social status, car ownership, area deprivation, occupational physical activity and recreational physical activity

$\mathrm{Cl}$, Confidence Intervals; RTVIS Road Traffic Volume Index Score.

warrants further research into what is the size of the local neighbourhood in conjunction with cycling [19]. Ideally it would be helpful also include measures of cycle path availability, alongside data on route choices by cyclists, who might choose to use roads with lower traffic volumes while cycling.

Future research should investigate the importance of traffic and include other possible psychological journey related correlates (e.g. attitude, confidence to cycling), by gender and age [20]. Models should consider the impact of environmental correlates at different distance around home for different types of cycling (commuting or leisure).

\section{Conflict of Interest}

The authors declare that they have no competing interests.

\section{Acknowledgements \& Funding}

We would like to thank the participants of the EPIC-Norfolk cohort. We also would like to thank the staff of Norfolk's local authorities and organizations as well the Ordnance Survey who provided us access to data.

The work was funded by the British Heart Foundation Project Grant (BHF/ PG/03/045) and our own institutions. We thank the Ordnance Survey/EDINA service who provided Road Network and Code Point data used in the analysis. CF is funded by the British Heart Foundation. JP is funded by
National Institute for Health Research and NW is funded by the Medica Research Council. NW and JP work under the auspices of the Centre for Diet and Activity Research (CEDAR), a UKCRC Public Health Research Centre of Excellence. Funding from the British Heart Foundation, Department of Health, Economic and Social Research Council, Medical Research Council and the Wellcome Trust, under the auspices of the UK Clinical Research Collaboration, is gratefully acknowledged.

\section{Author details}

${ }^{1}$ Department of Public Health, University of Oxford, UK. ${ }^{2}$ Medical Research Council Epidemiology Unit and Centre for Diet and Activity Research (CEDAR), Institute of Public Health, Cambridge, UK.

\section{Authors' contributions}

CF \& JP conceived of the study, and participated in its design and coordination and helped to draft the manuscript. NW participated in its design and coordination and helped to draft the manuscript. All authors read and approved the final manuscript.

Received: 3 March 2011 Accepted: 10 June 2011 Published: 10 June 2011

\section{References}

1. Woodcock J, Banister D, Edwards P, Prentice A, Roberts I: Energy and transport. Lancet 2007, 370:1078-1088.

2. Thompson DC, Rivara FP, Thompson RS: Effectiveness of bicycle safety helmets in preventing head injuries. A case-control study. Journal of the American Medical Association 1996, 276:1968-1973.

3. Hillman M: Children, Transport and Quality of Life. 1993.

4. Andersen LB, Schnohr P, Schroll M, HO H: All-cause mortality associated with physical activity during leisure time, work, sports and cycling to work. Arch Intern Med 2000, 160:1621-1628. 
5. Bassett DR, Pucher J, Buehler R, Thompson DL, Crouter SE: Walking, cycling and obesity rates on Europe, North America and Australia. Journal of Physical Activity and Health 2008, 5:795-814.

6. Heath G, Brownson RC, Kruger J, Miles R, Powell KE, Ramsey L: The effectiveness of urban design and land use and transport policies and practices to increase physical activity: A systematic review. Journal of Physical Activity and Health 2006, 3:55-76.

7. Panter JR, Jones AP: Attitudes and the environment: What do and don't we know? Journal of Physical Activity \& Health 2010, 7:551-561.

8. Troped PJ, Saunders RP, Pate RR, Reininger B, Ureda JR, Thompson SJ: Associations between Self-Reported and Objective Physical Environmental Factors and Use of a Community Rail-Trail. Preventive Medicine 2001, 32:191-200.

9. Titze S, Stronegger WJ, Janschnitz S, Oja P: Association of builtenvironment, social-environment and personal factors with bicycling as a mode of transportation among Austrian city dwellers. Preventive Medicine 2008, 47:252-259.

10. Foster $C$, Hillsdon M, Jones A, Grundy C, Wilkinson P, White M, Sheehan B, Wareham N, Thorogood M: Objective Measures of Physical Activity Results of the Environment and Physical Activity Study in English adults. Journal of Physical Activity \& Health 2009, 6:570-80.

11. Wareham NJ, Jakes RW, Rennie KL, Mitchell J, Hennings S, Day NE: Validity and repeatability of the EPIC-Norfolk Physical Activity Questionnaire. Int J Epidemiol 2002, 31:168-174.

12. Department for Transport: A bulletin of public transport statistics: Great Britain: 2003 Edition. London: The Stationery Office; 2003.

13. Department for Transport: Walking and Cycling: An Action Plan. The Stationery Office: London; 2004.

14. Altman D: Practical statistics for medical research. London: Chapman \& Hall/CRC; 1999.

15. Cochrane T, Davey R, Gidlow C, Smith G, Fairburn J, Armitage CJ, Stephansen H, Speight S: Small area and individual level predictors of physical activity in urban communities: a multi-level study in Stoke on Trent, England. International Journal of Environmental Research and Public Health 2009, 6:654-677.

16. Wendel-Vos WGC, Schuit AJ, de Niet R, Bossuizen HC: Factors of the physical environment associated with walking and bicycling. Medicine and Science in Sports and Exercise 2004, 36:725-730

17. Ogilvie D, Mitchell R, Mutrie N, Petticrew M, Platt S: Shoe leather epidemiology: active travel and transport infrastructure in the urban landscape. International Journal of Behavioural Nutrition and Physical Activity 2010, 7.

18. Troiano RP, Freedson PS: Promises and pitfalls of emerging measures of physical activity and the environment. American Journal of Preventive Medicine 2010, 38.

19. Smith G, Gidlow C, Davey R, Foster C: A pilot study of English adults' definitions of their local walking neighbourhoods - What is my walking neighbourhood? International Journal of Behavioural Nutrition and Physical Activity 2010, 276:1974

20. Titze S, Giles-Corti B, Knuiman MW, Pikora TJ, Timperio A, Bull FC, van Niel K: Associations between intrapersonal and neighborhood environmental characteristics and cycling for transport and recreation in adults: baseline results from the RESIDE study. Journal of Physical Activity \& Health 2010, 7:423-431.

doi:10.1186/1479-5868-8-61

Cite this article as: Foster et al:: Assessing the impact of road traffic on cycling for leisure and cycling to work. International Journal of Behavioral Nutrition and Physical Activity 2011 8:61.

\section{Submit your next manuscript to BioMed Central and take full advantage of:}

- Convenient online submission

- Thorough peer review

- No space constraints or color figure charges

- Immediate publication on acceptance

- Inclusion in PubMed, CAS, Scopus and Google Scholar

- Research which is freely available for redistribution

Submit your manuscript at www.biomedcentral.com/submit 